Louis A. Pérez, Intimations of Modernity: Civil Culture in Nineteenth-Century Cuba.

Chapel Hill: University of North Carolina Press, 2017. 272 pp. (Cloth Us\$39.95)

As Louis Pérez notes, the historiography of nineteenth-century Cuba follows a well-trod path portraying heroic men and women rallying around concepts of freedom to rise up against their colonial oppressors in 1895. Pérez argues that this "political" upheaval was preceded by almost a century of cultural change rooted in Cuba's emerging urban creole middle class. The rise of capitalist market forces and sugar wealth offered Creoles numerous consumer choices that pro-Spanish commentators abhorred, convinced that their control was slipping away. Middle-class choices in terms of consumption, travel, education, literature, fashion, and more created a growing conflict between creole concepts of modernity (increasingly seen as "Cuban") and almost every facet of Spanish tradition and rule that Cubans came to see as antimodern.

Pérez argues that as capitalism and market forces arrived on the island "vast numbers of women and men were transformed into agents - often unwittingly - of far-ranging cultural and social change, [which] contributed to the collapse of the moral infrastructure upon which the colonial system rested" (p. 3). Urban Creoles had new choices, creating new identities that conflicted with Spanish tradition, so that "the political mobilizations of the nineteenth century were consequences - and not causes - of larger moral transformations by which the logic of the status quo could no longer sustain the claim to credibility" (p. 4). The Cuban colony became more modern (that is capitalist) than the Spanish metropole which could no longer meet creole aspirations. Ultimately, "Cubans would presume to define their needs as different from and independent of Spanish interests" (p. 55).

Creole women (key to Pérez's argument) became more public and more engaged in culture and used new disposable income to purchase foreign fashions that challenged Spanish traditional sensibilities and led to female selfawareness in this emerging culture. As a result, they became "among the most visible proponents of a new ethos, by way of public demeanor as a matter of choice and style as prerogative of an emerging selfhood, as agents acting with an air of entitlement" (p. 139). This shop-'til-you-drop mentality rooted in capitalist consumerism was not some direct political statement, Pérez warns, because "it was not so much that they were defiant as that they were dismissive, persuaded perhaps that a moral order associated with defense of a colonial system at a time when the very proposition of colonialism was under assault no longer applied to them" (p. 140). 
The argument raises eyebrows: Can what a handful of white, middle-class colonial women wear signal an empire in crisis? If people are only half-conscious (or unconscious) of the impact of their consumer choices in creating a colonial crisis, can we say that such people are agents of change? And how half- or unconscious was this class? It's a contradiction weaving throughout the book. At times Creoles seem to be along for the ride, enjoying the consumer fruits offered by emerging markets. This does not sound much like agency. At other times the book claims the opposite: that a "new social class had selfconsciously assumed the role of agent of progress and modernity" (p. 102). Of course, what you do and portray with your purchases can be impactful, but is it agency? Some may argue that this is "performance" and thus agency, but what if the people are acting "unwittingly"?

If Pérez is correct, creole capitalist consumerism set the stage for independence by creating a bourgeois counterculture to challenge Spanish rule. Which raises the question: would these Creoles have been satisfied to sit around, wave their fans, buy their European fashion, and travel abroad, if working-class revolutionaries hadn't risen up against Spain? This what-if question isn't raised by Pérez, but it is relevant. Of course, capitalist modernity was not the only game in town. The artisan and urban labor movement had their own ideas about progress that were decidedly anticapitalist. And they were the ones to pick up guns. Still, if Pérez's creole modernism was the basis for disrupting acceptance of colonial rule, then it helps to explain how the working class never had a chance to bring forth its postindependence social revolutionary goals. The creole capitalist class's notions of modernity would rule the day after Spain's defeat.

Intimations of Modernity is a bit repetitive, especially about modernity and agency challenging Spanish tradition. Also annoying is the regular translation of Spanish words or phrases that are quite obvious or should have been in English in the first place. Finally, lovers of epigraphs will get their money's worth here; some chapters open with five or six. But these quibbles should not distract from an innovative, thought-provoking reexamination of pre-1898 Cuba and the forces that led to independence. It is worthy of a broad readership for those interested in Cuban history and late colonial history more generally.

\section{Kirwin Shaffer}

Humanities, Arts and Social Sciences, Penn State University-Berks College krs14@psu.edu 